\title{
Assessing the Walk-Score of Walking Paths in Kandy City Area for Better Walking Experience for the Tourists
}

\section{T.W.K.I.M. Dias and K.P. Wijeweera}

\begin{abstract}
Walking has been always considered as a sustainable method of transportation which is more suitable for short distance trips. It is observed that tourists would prefer to walk more than local residents in cities with many tourist attractions located in close proximity. The City of Kandy, in Sri Lanka, can be recognized as one good example for such cities. Even though the tourists are willing to walk longer distances, this study has assessed the walking experience of a pedestrian in the city limits of Kandy, based on a walk score. Several walkability characteristics are taken into account to generate the walk score for segments of roads in the city and Pedestrian Level of Service (PLOS) was also considered. The objective of this study was to recognize the best walking paths between the tourist attractions using these qualities. This study used an evaluation criterion previously developed by Dias in 2012 to obtain the walk-score, and tourism specific features such as availability of shops and ATM machines were considered. The study area was based on the tourist attractions in Kandy. Data were collected through field surveys in 2018 to identify walking facilities provided and to estimate PLOS in the selected street segments. Twenty-six road segments were selected for the study and the Walk-score ranged from $24 \%$ to $60 \%$ with an average of $45 \%$, which cannot be considered as a satisfactory situation. The results showed lack of pedestrian amenities in many street segments could be discouraging tourists to choose the street segment for their route. When selecting a walking path to reach a tourist destination it is expected that tourists will tend to select the best walking path.
\end{abstract}

Keywords: Walkability, Walk score, Pedestrian amenities, Tourism, Kandy

\section{Introduction}

Walking has been always considered as a sustainable method of transportation which is more suitable for short distance trips. There are several, but not many yardsticks available to measure walkability. When the definition is taken, "walkability" is simply how walking is facilitated by infrastructure and urban planning. Further, the concept of "short distance trip" changes with the convenient maximum walking distance of a human being. As a result, a resident might not walk longer distances as compared to a foreign tourist.

However, it is observed that tourists would prefer to walk more than local residents. Tourism has a significant relationship with walking. Most tourists like to feel the close connection to the environment through walking. This is noticeable specially in cities with many tourist attractions located within proximity and also when the weather is perceived as comfortable. In order to develop walking as a popular travel mode among the tourists, a city should have a variety of walking facilities provided to encourage walking. Most importantly tourists should be able to do walking as an active travel mode without any interruption. Tourists may use walking as a travel mode to reduce traffic congestion they may have to face during their trips.

\subsection{Background}

Kandy city, the cultural capital of Sri Lanka, is one of the major tourist attraction areas inside the country. City has prominent tourist attractions like temple of tooth, Old Royal Palace compound (headquarters of Malwatta and Asgiriya within its precincts) Annual Esala Perahara, Udawatte preserve and many cultural heritage sites. It was declared a world heritage site by UNESCO in 1988[1].

Eng. (Dr.) T.W.K.I.M. Dias, AMIE(SL), PhD (USA), MSc (Moratuwa), BSc Hons (Moratuwa), CMILT(SL), Senior

Lecturer, Department of Civil Engineering, General Sir John Kotelawala Defence University, Kandawala Road,

Ratmalana, Sri Lanka.

Email:ishanidias@kdu.ac.lk

(D) https://orcid.org/0000-0003-2503-5720

Second Lieutenant K.P. Wijeweera,

Department of Civil Engineering

General Sir John Kotelawala Defence University

Kandawala Road, Ratmalana, Sri Lanka. 
Within the Kandy city area, lesser foreign tourists could be observed due to lack of walking facilities and amenities. The sidewalks inside the city area are often overcrowded and it forces the pedestrians to use the road causing traffic congestion. It is important to analyse the adequacy of the walkways to facilitate higher pedestrian volumes without interruption. One basic requirement for pedestrians is sufficiently wide sidewalks. Within the Kandy city limits, walkways are obstructed due to many reasons and some are shown in Figures 1 to 3.

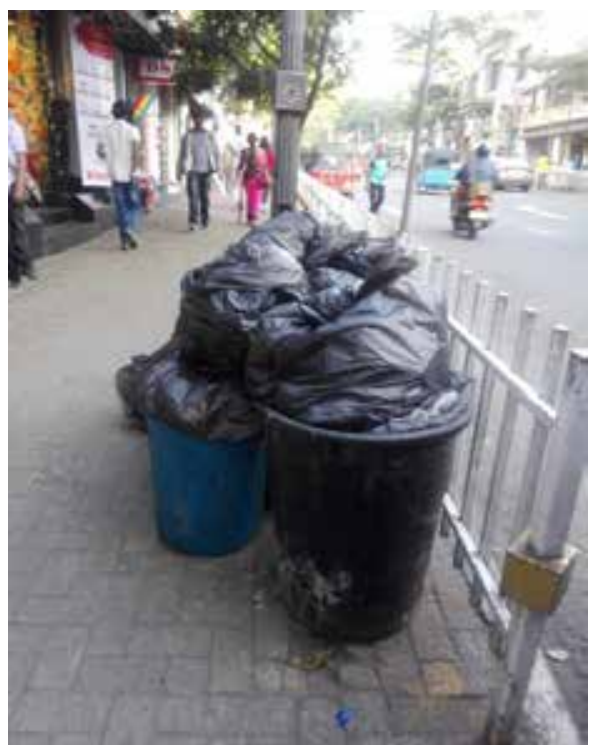

Figure 1 - Unsystematic Garbage Piles

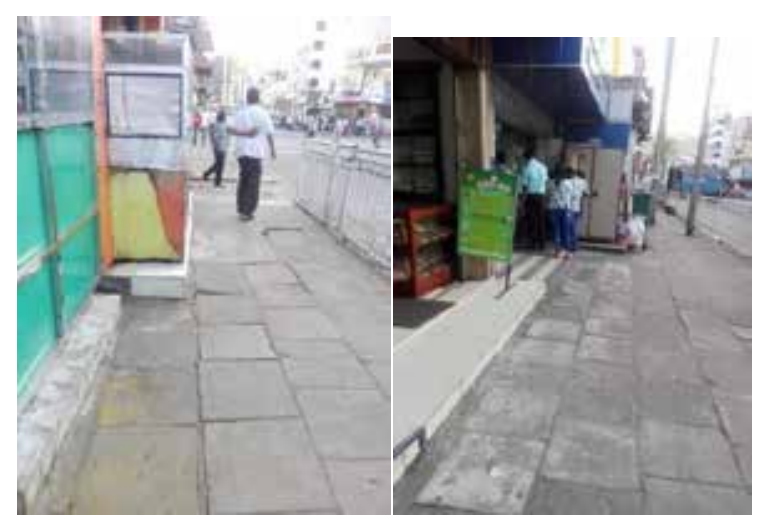

Figure 2 - Constructions Encroaching into the Sidewalks

The first objective of this study was to evaluate the Pedestrian Level of Service (PLOS) of the street segments within the Kandy City. The second objective was to estimate a walkscore for all the main street segments within the Kandy city between the Kandy Railway Station and the Municipal Council junction (entrance to the Udawatte Reserve). Then a strategy is proposed to choose the most preferred route connecting the street segments from a given origin to a destination covering the required tourist destinations.

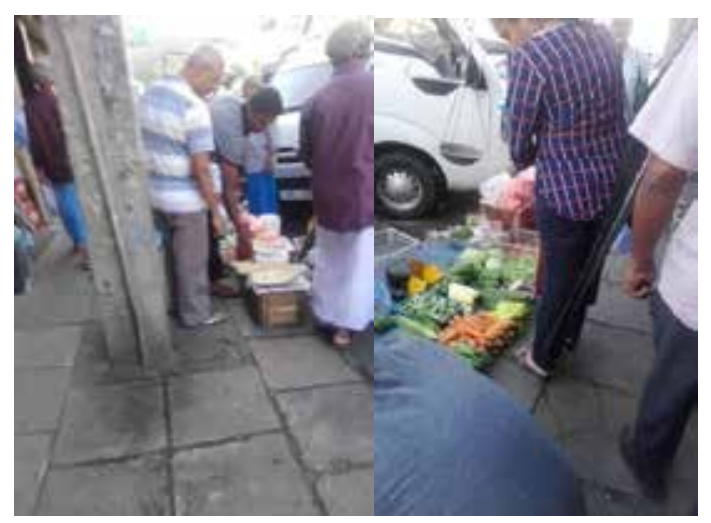

Figure 3 - Unfavorable Obstructions for Pedestrians

The outcome can be used to superimpose in a digital map of Kandy, so that a tourist can make an informed decision on which road links to use to reach a particular destination from their origin. This could also be used to plan out a walking route to cover all the tourist attractions within the city.

Factors that need to be considered in order to develop a walkscore are, walkway width, pedestrian amenities, recreational activities, etc. Walking is a good solution to prevent unnecessary traffic congestion, but there are better walking routes within the city which are not recognized by the tourists. Thus, tourists are not well informed.

\section{Literature Review}

Tourists who ever come to visit some place are mostly like to walk through the destination and in-between their journey. As tourism becomes more sustainable, there is interest in encouraging tourists to use an active travel mode when visiting destinations. A study done by Kumarage and Bandara (2018) has proven that tourists are willing to walk to the destinations which are more attractive and it has also mentioned that most of the tourists believe that walking is the best way to experience the city [2]. Hall and Ram (2017) have identified that walkability affects urban as well as rural tourism in many ways [3]. Furthermore, tourists are also interested in walking through built-up environments which is potentially an asset for tourist attraction and services such as transport, accommodation, restaurants. It is also mentioned that tourists are not only interested in walking and they use walking as a travel mode to maximize sightseeing.

In contrast with the interest to walk, an individual's willingness to walk varies greatly 
depending on age, health, time availability, quality of surroundings, safety, climate, and many other factors. As the convenient maximum walking distance varies for different individuals, an average distance of $400 \mathrm{~m}$ can be accepted [4].

\subsection{Pedestrian Level of Service}

Pedestrian Level of Service (PLOS) is defined by the Highway Capacity Manual (HCM) and the version considered in this study is 2000 [5]. Use of PLOS concept to evaluate walking conditions is not new and it was observed in past literature as well. Miranda and Carrasco (2011) in their study have discussed various practical methods to obtain pedestrian data for these studies [6]. They have found that pedestrians walking in the same direction chooses the side of the road that has wider sidewalks to do their walk. Shaban and Muley (2016) studied the impact of weather conditions on pedestrian volume and they have discussed the importance of considering all seasons for pedestrian studies [7]. Sony and Destri (2018) have studied various PLOS methods other than $\mathrm{HCM}$ and concluded that the evaluations vary but the recommendations related to effective walking width improvements are much more reliable through HCM [8].

\subsection{Evaluating the Walkscore}

Sidewalks are defined as the backbone of the pedestrian transportation network. Sidewalks narrow than $1.5 \mathrm{~m}$ are not encouraged to be proposed for the score cards and sidewalks more than $1 \mathrm{~m}$ can score because of the presence of the sidewalks [9]. According to Dias (2012), the effective length of an obstruction is considered as five times its effective width and it further reduces the effective area of the sidewalk [9].

Connectivity factor which can describe as connectivity to the main roads, linkage to other important walking paths which have higher scenic views also very important when considering walking of tourists[10].

Buffers along sidewalks can be provided to increase pedestrian comfort by increasing the lateral separation between pedestrians and fastmoving cars [9]. These buffers can be landscaped and include street trees, green infrastructure, street infrastructure such as light toilet or utility poles, and transit stops. They also provide space for driveway pads while allowing the sidewalk to remain level. Presence of buffers is taken as a measuring element by Dias (2012) in the walkability evaluation criterion. Other than that, modal conflict is safeguarded by elevated sidewalks and that is also considered in the same criterion.

Walkways should be comfortable for all road users including differently abled people. Disability infrastructure listed by Dias (2012) is shown in Table 1.

Pedestrians seek frequent crossing points for their convenience. Most people will walk 150 feet $(46 \mathrm{~m})$ to get to locations rewarding their arrival. If pedestrian crossings are not available at frequent distances, pedestrians tend jaywalk and increase the ability for road crashes [9].

\section{Table 1 - Disability Infrastructure - Survey Form Section}

\begin{tabular}{|c|l|c|c|}
\hline & Disability Infrastructure & YES & NO \\
\hline i & Correctly placed tactile paving along the sidewalks & YES & NO \\
\hline ii & Correctly placed tactile paving along the crossings & YES & NO \\
\hline iii & Gradient/ slope of sidewalks are convenient (less then 1:20) & YES & NO \\
\hline iv & Cross slopes are convenient (less than 1:50) & & \\
\hline & $\begin{array}{l}\text { Dropped curbs/ curb ramps are present at road junctions where there is a } \\
\text { v }\end{array}$ & YES & NO \\
\hline vi & Water does not pool on pathways & YES & NO \\
\hline vii & No open drains/ tree routes across pathways & YES & NO \\
\hline viii & Central ramps with flared sides & YES & NO \\
\hline ix & Ramp surface is wider than 900mm & YES & NO \\
\hline x & Ramps have non-slip surfacing & YES & NO \\
\hline xi & Color of ramps and flare sides are in contrast with surrounding & YES & NO \\
\hline xii & $\begin{array}{l}\text { Curb ramps leave at least 900mm of the pathway and do not obstruct through } \\
\text { flow }\end{array}$ & YES & NO \\
\hline xiii & No overhead obstructions below 2200 mm & YES & NO \\
\hline xiv & Audible warnings at pedestrian crossings & YES & NO \\
\hline
\end{tabular}


In many studies it is found that pedestrian friendly community include safety, weather, distance, lifestyle, and best suited layout that is having flat terrain, mild climate, interconnected network allows to develop pedestrian friendly community[11][12]. In that research, it was also mentioned that importance of building recreational paths and walk paths should be designed knowing that residents are willing to walk 10-15 minutes at a time. Some have identified factors affecting the walkability as continuity, connectivity, absence of barriers, linkage to the transport modes, safety from traffic, physical condition of the path and contextual values such as aesthetic and historic values[13].

A study done for Dhaka city, identified walking parameters as walking path modal conflict $(15 \%)$, availability of walking paths $(25 \%)$, availability of crossings $(10 \%)$, grade crossing safety $(10 \%)$, motorist behavior $(5 \%)$, amenities $(10 \%)$, disability infrastructure $(10 \%)$, obstructions $(10 \%)$ and security from crime $(5 \%)$ and all these parameters have given different weight to determine the walkability ratings (which are given within brackets) [14].

According to a study done to compare neighbourhood walkability to community facilities in Putrajaya emphasized that, facilities such as, grocery/supermarket, parks or recreational facilities (indoor and outdoor), elementary schools, other schools, community centres, banks, bus stops, post offices, and pharmacies and their availability within $400 \mathrm{~m}$, increase the tendency of walking [15].

\section{Methodology}

The study area is Kandy City and 26 street segments in the city as shown in Figure 4 are analysed. High pedestrian volumes can be observed in the morning peak hours where commuters, school children and many other pedestrians are included on a regular day. In the month of July, Esala Perahara (also known as Kandy procession) is starts and held for ten days. Data collection was done in the abovementioned roads during both in season and offseason time periods.

\subsection{Pedestrian Level of Service (PLOS)}

PLOS was considered in this study only as a check to determine whether the minimum required pedestrian facilities are available on the selected road segments. Facilitating the foreign or local tourists in walking could become the second need to improve the walking infrastructure in the city.

To evaluate the PLOS for each segment, Highway Capacity Manual (2000) [5] was used.

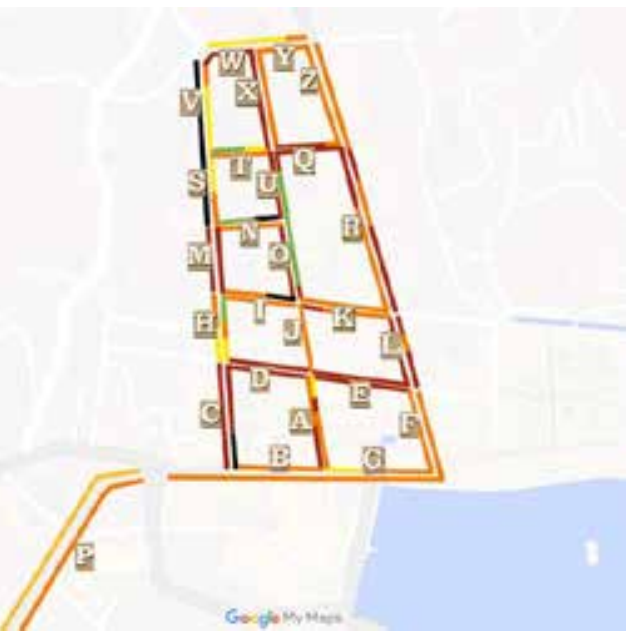

Figure 4 - Street Segments on a Map

In summary, the steps involved in estimating PLOS are as follows:

Step 1: Measure walkway width (m) - $W_{t}$ Step 2: Find the sum of obstructions (m) - $W_{o}$ Step 3: Calculate effective width (m) - $W_{e}$ Step 4: Measure peak 15-min flow (p/15-min) $V_{15}$

Step 5: Calculate pedestrian flow rate $(\mathrm{p} / \mathrm{min} / \mathrm{m})-V_{P}$

Step 6: determine pedestrian level of service

Exhibit 18-6 of HCM (2000) lists the average flow LOS criteria for walkways and sideways.

However, it is important to note that HCM does not provide PLOS evaluation measures for pedestrian activity where pedestrian walk on roadway, bicycle lanes. For these locations PLOS as a concept is considered LOS F as well as for situations where pedestrian platooning occurs. Platoon-adjusted LOS criteria could be found in Exhibit 18-4 [5]. Flow rates less than 16 $\mathrm{p} / \mathrm{min} / \mathrm{m}$ is $\operatorname{LOS} A, 16-23$ is $\operatorname{LOS} B, 23-33$ is LOS $C, 33-49$ is LOS $D, 49-75$ is LOS $E$ and when available pedestrian space is less than $0.75 \mathrm{~m}^{2} / \mathrm{p}$ and when the flow rate varies, the LOS is considered as $F$. The platoon adjusted flow rates range from 1.6 to $59 \mathrm{p} / \mathrm{min} / \mathrm{m}$.

Field data were collected on walking weekdays from $7.00 \mathrm{am}$ to $10.00 \mathrm{am}$ to identify the morning peak hour and $3.00 \mathrm{pm}$ to $6.00 \mathrm{pm}$ to identify the evening peak hour. 


\subsection{Determining the Walkscore}

Walkscore was evaluated using several aspects. Walkability measurement criterion proposed by Dias [9] was used for these aspects.

- Presence and continuity of side walks

- Effective width of sidewalks

- Modal conflict

- Presence of buffer

Buffers along sidewalks can be provided to increase pedestrian comfort by increasing the lateral separation between pedestrians and fastmoving cars [9]. These buffers can be on-street parking spaces, landscaped and including street trees, green infrastructure, bicycle lanes, street infrastructure such as lighting or utility poles, or bollards etc.. They also provide space for driveway pads while allowing the sidewalk to remain level.

Score $=\frac{\begin{array}{c}\text { Total length of sidewalk } \\ \text { that satisfy } \\ \text { the minimum width } \\ \text { of buffer }\end{array}}{\begin{array}{c}\text { Total length } \\ \text { of the street segment }\end{array}} * 100 \%$

- Elevation difference between

sidewalks and carriageway

Height difference of the sidewalks and the carriageway affects the protection of the pedestrian from motorized or non-motorized traffic flow. Most of the countries, instead of raising the whole sidewalk, only the curb length is raised up to some level to prevent conflict between pedestrians and motor traffic. If such curb is available, it should be taken in account as same as a raised sidewalk[9]. Elevation of the curb depend on the Annual Daily Traffic (ADT) of the conflicting road network and its land use [9].

Total length of sidewalk that satisfy

Score $=\frac{\begin{array}{c}\text { the minimum height } \\ \text { of sidewalk }\end{array}}{\begin{array}{c}\text { Total length of the } \\ \text { street segment }\end{array}} * 100 \%$

- Disability infrastructure

Walking should be comfortable for all road users including people with disabilities, parents using baby strollers, etc. Score for this is evaluated according to the disability infrastructure proposed by Dias [9] (See Table 1).

- Availability of crosswalks

- Distance to pedestrian (tourist) amenities

- Banks

- ATMs

- Restaurants

- Shopping malls

- Public transportation
A Tourists may have their own preference to these amenities depending on their requirements. Hence, as an output level, when the concept proposed in this paper is available through a digital version - as a mobile application, the users can feed their preference to the application. Then, a factored score will be calculated from Equation 3.

Score for amenities $=\frac{\sum_{i=1}^{n} C_{i} F_{i}}{n}$

Where, $C_{i}$ is the score related to the distance to each amenity and $F_{i}$ is the weight factor for each amenity.

A similar method used by Cubukcu et al (2015) in their study [16].

By allowing the users to choose the weight factor according to their preference will improve the suggested paths in a customized manner.

The weight factors used for these sample calculations are shown in Table 4.

- Availability of aesthetic views or recreational areas

Only four road segments among these 26 segments scored to have aesthetic views or recreational areas. Those were: Segments B, D, $\mathrm{E}$, and $\mathrm{F}$. Hence this factor was removed from the final analysis to prevent bias.

\subsection{Identifying the Street Segments}

Street segments are codes by alphabetical letters such as Greek letters as shown in Figure 4. The list of names of the considered roads is shown in Table 2. Even though walkscore was determined for 26 road segments, PLOS was determined for three extra road segments.

Table 2 - Street Names and Included Segments

\begin{tabular}{|l|l|r|}
\hline \multicolumn{1}{|c|}{ Street name } & Letter Coding & $\begin{array}{c}\text { \# } \\
\text { of road } \\
\text { segments }\end{array}$ \\
\hline EL Senanayake Street & $\mathrm{A}, \mathrm{J}, \mathrm{O}, \mathrm{U}, \mathrm{X}$ & 5 \\
\hline Sri DaladaVeediya & $\mathrm{B}, \mathrm{G}$ & 2 \\
\hline YatinuwraVeediya & $\mathrm{C}, \mathrm{H}, \mathrm{M}, \mathrm{S}, \mathrm{V}$ & 5 \\
\hline Colombo Street & $\mathrm{D}, \mathrm{E}$ & 2 \\
\hline DS Senanayake Street & $\mathrm{F}, \mathrm{L}, \mathrm{R}, \mathrm{Z}$ & 4 \\
\hline Raja Veediya & $\mathrm{I}, \mathrm{K}$ & 2 \\
\hline Kumara Veediya & $\mathrm{N}$ & 1 \\
\hline $\begin{array}{l}\text { SWRD Bandaranayake } \\
\text { Mawatha }\end{array}$ & $\mathrm{P}$ & 2 \\
\hline KandeVeediya & $\mathrm{W}, \mathrm{Y}$ & 2 \\
\hline Cross Street & $\mathrm{Q}, \mathrm{T}$ & 1 \\
\hline Kappetipola Mawatha & $\alpha$ & 1 \\
\hline $\begin{array}{l}\text { Sri WickramaRajasinghe } \\
\text { Mawatha }\end{array}$ & $\beta$ & 1 \\
\hline Sangaraja Mawatha & $\gamma$ & \\
\hline
\end{tabular}




\section{Results and Discussion}

\subsection{Pedestrian Level of Service Calculations} Examples of PLOS estimations are given below. Street segment A is considered as EL Senanayake Street. Several important amenities and restaurants are located on this street and this road segment is crowded because of the Kataragama Kovil located on the roadside. PLOS and walk score evaluation sheets for segment $\mathrm{A}$ are provided in Table 3, 4 and 5.
Table 3 -PLOS Calculations for Road Segment A

\begin{tabular}{|c|c|c|c|c|c|c|}
\hline \multicolumn{3}{|c|}{ LOCATION } & $=$ & A & & \\
\hline \multicolumn{2}{|c|}{ WALKWAY WIOTH $(m)$} & $w_{t}$ & $=$ & 23 & & \\
\hline \multicolumn{2}{|c|}{ SUM OF OBSTRUCTION (m) } & $w_{0}$ & $=$ & 0.4 & & \\
\hline \multicolumn{2}{|c|}{ PEAK 15-MAN FLOW RATE } & $V_{45}$ & $=$ & 912 & & \\
\hline STEP 1 & \multicolumn{2}{|c|}{$\begin{array}{l}\text { WIOTH AOIUSTMENTS/SHY } \\
\text { OISTMNCE) TO WRUKWAY (m) }\end{array}$} & \multicolumn{2}{|c|}{$W_{e}=W_{t}-W_{e}$} & $=$ & 1.9 \\
\hline STEP 2 & \multicolumn{2}{|c|}{$\begin{array}{l}\text { PEOESTRLAN FLOW RATE } \\
\text { ip } / \text { min } / m\end{array}$} & \multicolumn{2}{|c|}{$V_{p}=\frac{V_{15}}{15 \cdot W_{s}}$} & $=$ & 32 \\
\hline STEP 3 & \multicolumn{5}{|c|}{ PLOS } & 0 \\
\hline
\end{tabular}

Table 4 - Distance to Pedestrian Amenities - Score for Road Segment A

\begin{tabular}{|c|c|c|c|c|c|c|}
\hline Segment & Factor & Equation & Amenity & $\begin{array}{l}\text { Weight } \\
\text { Factor }\end{array}$ & $\begin{array}{l}\text { Score } \\
\text { for the } \\
\text { distance }\end{array}$ & $\begin{array}{l}\text { Final } \\
\text { Score }\end{array}$ \\
\hline \multirow{5}{*}{ A } & \multirow{5}{*}{$\begin{array}{l}\text { Accessibility } \\
\text { to amenities }\end{array}$} & \multirow{5}{*}{$\begin{array}{l}\text { Score for amenities } \\
\quad=\frac{\sum_{i=1}^{n} C_{i} F_{i}}{n}\end{array}$} & Banks & 0.75 & 89.60 & \multirow{5}{*}{56.68} \\
\hline & & & Restaurants & 1.00 & 100.00 & \\
\hline & & & Shopping malls & 0.75 & 100.00 & \\
\hline & & & $\begin{array}{l}\text { Bus stops/train } \\
\text { stations }\end{array}$ & 0.50 & 52.37 & \\
\hline & & & ATMs & 0.25 & 60.00 & \\
\hline
\end{tabular}

Table 5 - Further Estimation of Scores - Road Segment A

\begin{tabular}{|c|c|c|c|c|}
\hline Road Segement & $\mathbf{A}$ & & & \\
\hline Main Factor & Equation & Considered Factor & Data & Score $\%$ \\
\hline \multirow{2}{*}{$\begin{array}{l}\text { Presence and } \\
\text { continuity of side } \\
\text { walks }\end{array}$} & $\sum$ Discontinuity lengths & Total walkway length (m) & 137 & \multirow{2}{*}{100} \\
\hline & score $=(1 \overline{\text { Total ledngth of the street }})$ & Legth of discontinuity (m) & 0 & \\
\hline \multirow{2}{*}{ Effective width } & \multirow{2}{*}{ Score $=\frac{\text { that satisfy the minimum width }}{\text { Total length of the street segment }}$} & Total walkway width (m) & 1.4 & \multirow{2}{*}{0} \\
\hline & & $\begin{array}{l}\text { Effective length that satisfy the } \\
\text { minimum width }(\mathrm{m})\end{array}$ & 0.5 & \\
\hline \multirow{2}{*}{ Present of buffer } & \multirow{2}{*}{ Score $=\frac{\begin{array}{c}\text { Total length of side walk that satisfy } \\
\text { the minimum width of buf fer }\end{array}}{\text { Total length of the street segment }} * 100 \%$} & Total walkway length (m) & 137 & \multirow{2}{*}{0} \\
\hline & & $\begin{array}{l}\text { Sidewalk length that satisfy the } \\
\text { minimum width of buffer }(\mathrm{m})\end{array}$ & 0 & \\
\hline \multirow{2}{*}{$\begin{array}{l}\text { Height different } \\
\text { between side walks } \\
\text { and carriageway }\end{array}$} & \multirow{2}{*}{ Score $=\frac{\begin{array}{c}\text { Total length of side walk that satisfy } \\
\text { the minimum height of sidewalk }\end{array}}{\text { Total length of the street segment }} * 100 \%$} & Total walkway length (m) & 137 & \multirow{2}{*}{0} \\
\hline & & $\begin{array}{l}\text { Sidewalk legth that satisfy the } \\
\text { minimu height of sidewalk }(\mathrm{m})\end{array}$ & 0 & \\
\hline
\end{tabular}

\subsection{Distances to the Nearest Pedestrian Amenities/Services}

Figure 5 shows the Color-Coded Map according to the distances to the banks and ATMs. The key to the color code shown in Figure 5 is applicable to Figure 6,7 and 8 as well. Figure 6 shows the Color-Coded Map according to the distances to the restaurants. Figure 7 shows the Color-Coded Map according to the distances to the shopping malls. Figure 8 shows the Color-Coded Map according to the distances to the bus stops or railway stations.

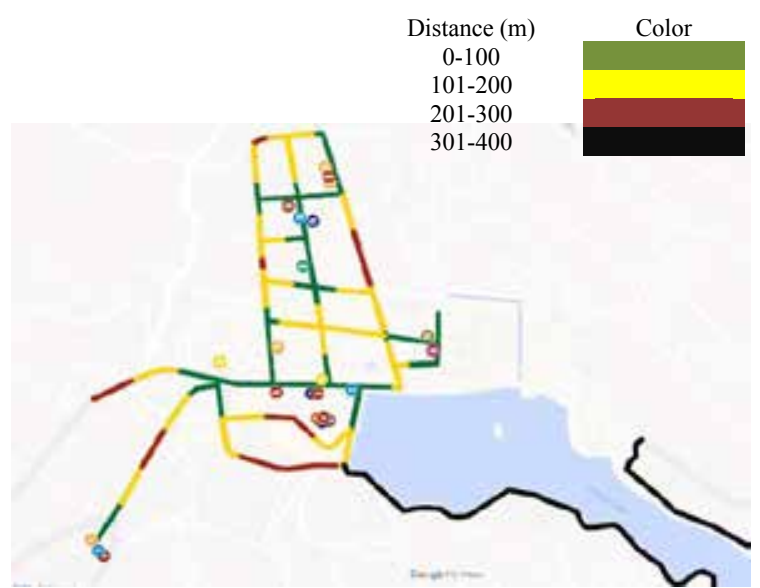

Figure 5 - Color-Coded Map for - Banks and ATMs 


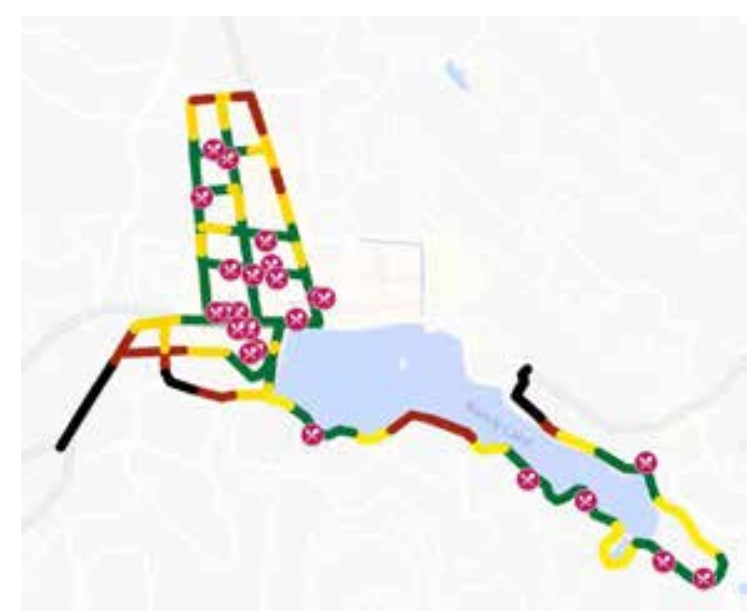

Figure 6 - Color-Coded Map for - Restaurants

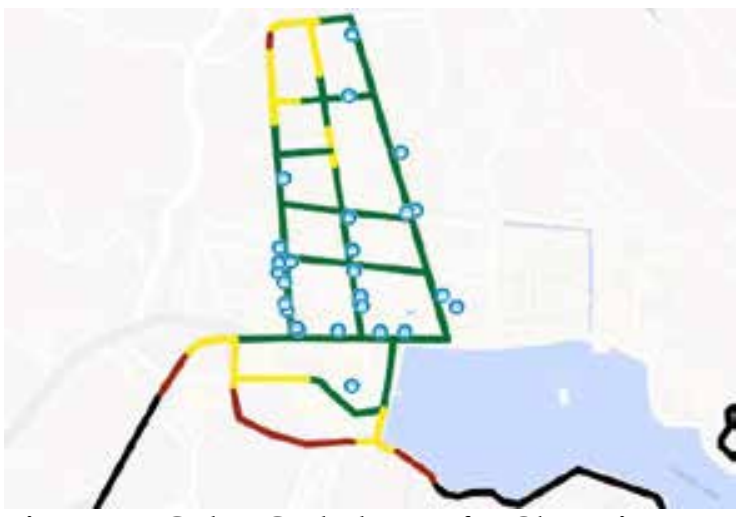

Figure 7 - Color-Coded Map for Shopping Malls

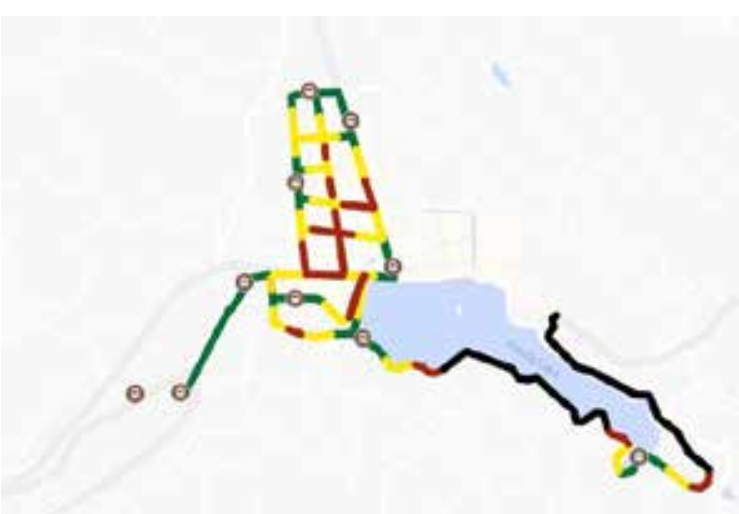

Figure 8 - Color-Coded Map Bus Stops or Railway Stations

\subsection{Aesthetics}

The total or the average walk-score shown in Table 6 has not incorporated aesthetics factor. Satisfactory levels of aesthetics or the availability of recreational areas were scored by only four street segments, namely $B, D, E$, and F.

Considered recreational areas were parks, roadside benches, availability of trees for shade etc. Although street segment $\gamma$ does not have a higher walk score, it has higher number of recreational areas like parks, tennis courts and activities like boat rides. Amenities like trees, benches at lake side, higher number of hotels and restaurants are also available in this street segment.

\subsection{Total Walkscore}

When all the above parameters are considered, a total walkscore can be generated assuming equal weight to each parameter. If an opinion survey could be conducted to take the preference for each parameter from the foreign and local tourists, a weightage could be determined. However, that task was not carried out during the study period. Table 6 lists the names of the road segments, in a descending order from the highest walkability to the lowest. With that, it is observed that the highest walkscore obtained by a street segment in the Kandy city is $65 \%$, which is not so satisfactory. Furthermore, when the PLOS is considered, the street segment with the highest walk score " $G$ " has PLOS of F which is the worst condition. It shows that, even though some street segments are facilitated with sufficient amount of walkability measures, due to high pedestrian volumes, the Level of Service for pedestrians is lower. If PLOS A is considered as 100, and PLOS F as zero and respectively, PLOS can be included to estimate the average walkscore, in that manner, street segment " $G$ " gets $57 \%$. However, that decision can be made by each tourists by themselves depending on their priorities or preferences. It is also emphasized that the best route suggested through the highest walk score may or may not be the shortest path between the selected origin and the destination. Hence it has to be understood that it is always the decision of the tourist to decide what they value and select the route accordingly.

\subsection{Walk Score for a Selected Walking Path}

Here, it is shown how to take an informed decision on choosing the most favourable route from an origin to a destination. The estimated walk scores in Table 6 are uses. A route consists of one or more street segments and as a combination. If the distance factor is put aside, this concept can be discussed more elaboratively, when two alternative routes with similar trip length is considered. An example is from the Kandy Railway Station to the Temple of Tooth Relic (Maligawa).

Figure 9 shows the shortest route Route 1 from the Kandy Railway Station to the Temple of Tooth Relic (Maligawa), but to discuss the walk score, two other alternatives are recognized to 
fulfil that trip: Route 2 (Figure 10) and Route 3

(Figure 11).

\section{Table 6 - Total Walk-Scores (without amenities)}

\begin{tabular}{|c|c|c|c|c|c|c|c|}
\hline \multirow{2}{*}{ 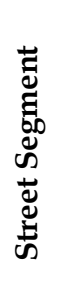 } & \multirow[b]{2}{*}{ 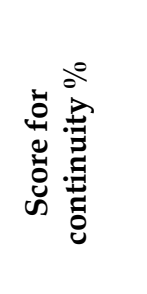 } & \multirow{2}{*}{ 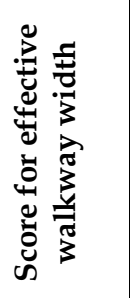 } & \multicolumn{2}{|c|}{ Modal conflict } & \multirow{2}{*}{ 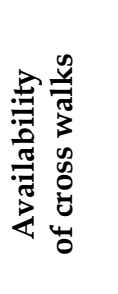 } & \multirow[b]{2}{*}{ 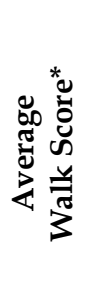 } & \multirow[b]{2}{*}{$\stackrel{n}{2}$} \\
\hline & & & Buffer & $\begin{array}{c}\text { Height difference } \\
\text { between sidewalk } \\
\text { and carriageway }\end{array}$ & & & \\
\hline $\mathrm{P}$ & 100 & 80 & 100 & 100 & 0 & 76.0 & \\
\hline G & 100 & 59.4 & 0 & 100 & 100 & 71.9 & $\mathrm{~F}$ \\
\hline $\mathrm{H}$ & 100 & 80 & 0 & 100 & 50 & 66.0 & $\bar{E}$ \\
\hline $\mathrm{Q}$ & 100 & 79.5 & 0 & 100 & 50 & 65.9 & C \\
\hline $\mathrm{U}$ & 100 & 66.7 & 0 & 61 & 100 & 65.5 & $\mathrm{E}$ \\
\hline$x$ & 100 & 73.9 & 0 & 100 & 50 & 64.8 & $\mathrm{D}$ \\
\hline$Y$ & 100 & 73.9 & 0 & 100 & 50 & 64.8 & $\mathrm{D}$ \\
\hline $\mathrm{F}$ & 100 & 86.4 & 0 & 0 & 100 & 57.3 & $\mathrm{D}$ \\
\hline $\mathrm{Z}$ & 100 & 84 & 0 & 0 & 100 & 56.8 & $C$ \\
\hline B & 100 & 82.1 & 0 & 0 & 100 & 56.4 & $\mathrm{~F}$ \\
\hline $\mathrm{K}$ & 100 & 80.9 & 0 & 90 & 0 & 54.2 & $C$ \\
\hline $\mathrm{R}$ & 100 & 64.8 & 0 & 0 & 100 & 53.0 & C \\
\hline$W$ & 100 & 63.7 & 0 & 100 & 0 & 52.7 & $E$ \\
\hline $\mathrm{T}$ & 100 & 0 & 0 & 100 & 50 & 50.0 & $\mathrm{D}$ \\
\hline$C$ & 69 & 75 & 0 & 100 & 0 & 48.8 & $\mathrm{E}$ \\
\hline $\mathrm{L}$ & 100 & 42.9 & 0 & 0 & 100 & 48.6 & $E$ \\
\hline $\mathrm{O}$ & 100 & 62.5 & 0 & 0 & 50 & 42.5 & $\bar{E}$ \\
\hline $\mathrm{E}$ & 100 & 0 & 0 & 100 & 0 & 40.0 & $\mathrm{D}$ \\
\hline $\mathrm{M}$ & 100 & 94.4 & 0 & 0 & 0 & 38.9 & $\mathrm{E}$ \\
\hline I & 100 & 0 & 0 & 79 & 0 & 35.8 & C \\
\hline A & 100 & 0 & 0 & 0 & 50 & 30.0 & $\mathrm{D}$ \\
\hline$\overline{\mathrm{V}}$ & 0 & 80 & 0 & 0 & 50 & 26.0 & $\bar{E}$ \\
\hline $\mathrm{N}$ & 64 & 0 & 0 & 13 & 50 & 25.4 & $C$ \\
\hline $\mathrm{J}$ & 100 & 0 & 0 & 0 & 0 & 20.0 & $\mathrm{~F}$ \\
\hline $\mathrm{D}$ & 100 & 0 & 0 & 0 & 0 & 20.0 & $\mathrm{D}$ \\
\hline $\mathrm{S}$ & 0 & 80 & 0 & 0 & 0 & 16.0 & $\mathrm{E}$ \\
\hline
\end{tabular}

*This average score is calculated without the score for the distance to amenities.

Note: Scores for disability infrastructure were zero for all road segments. Hence, it was removed from the table. 


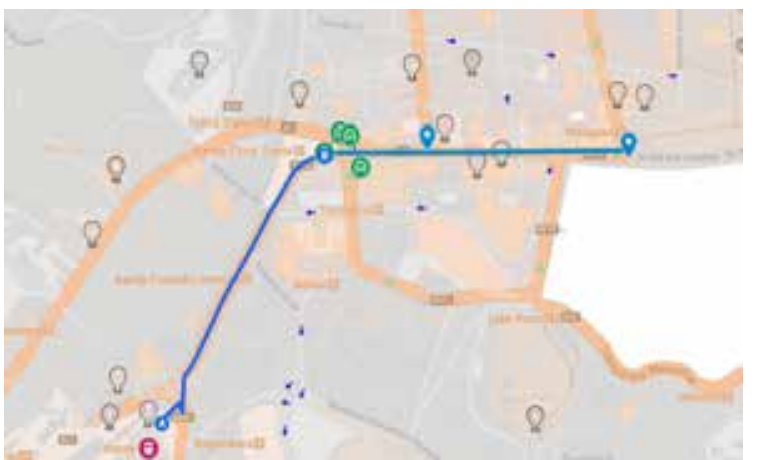

Figure 9 - Shortest Route from the Railway Station to Maligawa (Route 1)

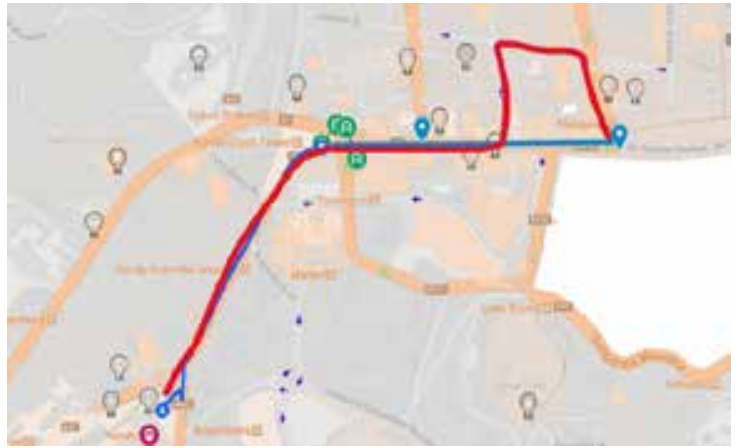

Figure 10 - Route 2 (P-B-A-E-F)

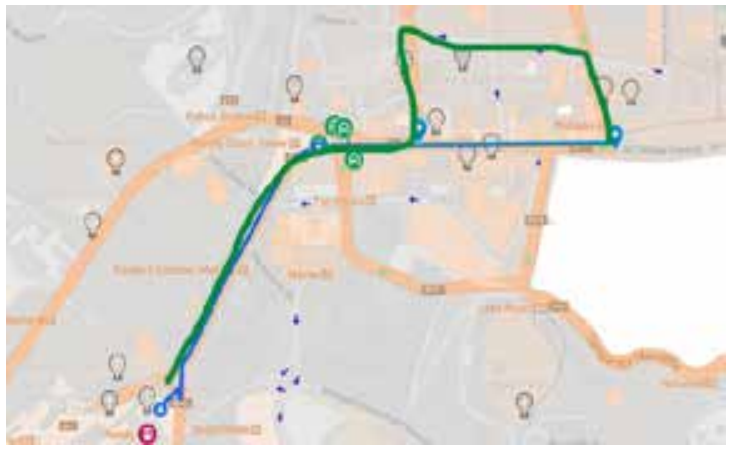

Figure 11 - Route 3 (P-C-D-E-F)

As indicated in Table 7, the shortest path has the highest walk score and a tourist may choose that path. If they were to select between Route 2 and 3, both the Routes 2 and 3 have trip lengths of $971 \mathrm{~m}$, but the walk score for Route 2 is slightly higher than Route 3 . Hence, it is clear that a pedestrian (tourist) can make an informed decision using these results.

Table 7 - Walk Score Comparison for Route 1 and 2

\begin{tabular}{|c|c|c|c|}
\hline $\begin{array}{c}\text { Route } \\
\text { No. }\end{array}$ & $\begin{array}{c}\text { Street } \\
\text { segments } \\
\text { included in } \\
\text { order }\end{array}$ & $\begin{array}{c}\text { TripLength } \\
(\mathrm{m})\end{array}$ & $\begin{array}{c}\text { Walk } \\
\text { Score } \%\end{array}$ \\
\hline 1 & P-B-G & 738 & 54.88 \\
\hline 2 & P-B-A-E-F & 971 & 49.60 \\
\hline 3 & P-C-D-E-F & 971 & 48.86 \\
\hline
\end{tabular}

\section{Conclusions}

Twenty-six (26) street segments were selected to evaluate walk score from the Kandy city area. HCM 2000 was used to evaluate Pedestrian Level of Service for the selected street segments. By conducting pedestrian surveys during both morning and evening peak hours, it was identified that the higher pedestrian volume occurs on the road during the morning peak hours. Collected data was taken used to calculate PLOS and to check the adequacy of the walkway segments under two parameters, continuity, and effective walkway width.

Evaluation of walk score of the street segments was done according to a developed method by Dias in 2012 [9] and suitable approaches were also studied from other literature. Walkscore for each street segment basically indicates a qualitative measure of the street segment and it was given a quantitative nature considering several parameters. In this study, all parameters were given equal weight. However, due to limited availability, aesthetics and recreational areas were not incorporated into the total average walk score. Finally, total walk score is evaluated from taking the average walk score from each category and given a single walk score for each street segment.Walk scores are given considering factors that are important to both local and foreign tourists in the city. Road segment J on EL Senanayake Street has lowest PLOS value, which calls for widened sidewalks.

When selecting the best walking route from an origin to a destination, a local tourist may not want to select a longer route instead of the shortest path, unless they want to access an ATM or a restaurant etc. For any of these preferences, this study gives sufficient data for a user to take an informed decision. This is done by considering each street segment's length with the total route length.

Outcome of this study has to be developed into a mobile or web application. With such facility, amenities will be indicated on a map. No weightages were given for the amenities as the weightage can vary between local and foreign tourist groups. However, the mobile app could be developed in a way that the user can select their own preference to those amenities and get the output customized to their needs. In that case, this concept can be used by both local and foreign tourists. 
This study has assessed how walkable the Kandy city is. Also, the municipal council can recognize the road segments which require improvements and road segments that are lacking the minimum requirements for pedestrians. This can be used when prioritizing funding allocations as well. It is realized from the literature review that improved pedestrian facilities reduce traffic congestion in downtown road segments.

Many road segments got lower PLOS due to frequent obstructions to pedestrians. These include improper garbage disposal, street vendors, unauthorized constructions encroaching into the sidewalks. Hence, it is important to remove such obstructions to optimize the available walking space. One other factor is installing roadside benches where pedestrian crowding occurs, and where sufficient space is available. It should be noted to maintain them clean without bird drops etc.

\section{References}

1. Sacred City of Kandy - UNESCO World Heritage Centre. Published 2020. Accessed June 2, 2018. http://whc.unesco.org/en/list/450.

2. Kumarage, A. S., Bandara G. Sustainable Transport Plan for Kandy. In: Conference: Civil Engineering Society University of Peradenya. ; 2017. Accessed January 31, 2021. https://www.researchgate.net/publication/328 051839_Sustainable_Transport_Plan_for_Kandy.

3. Hall, C. M., Ram, Y., Measuring the Relationship between Tourism and Walkability? Walk Score and English Tourist Attractions. Journal of Sustainable Tourism. 2018;27(2):223-240. doi:10.1080/09669582.2017.1404607.

4. Pratama, Y., Setiawan, L. B., Afif, Z., Anugerah, A. A., Identifying Public Facilities Surrounding MRT Stations Based on Pedestrian Walking Distance using GIS-Based Buffer and Spatial Query Method (Case study: Central and South Jakarta). In: SuperMap Cup 2018. ; 2018. Accessed January 31, 2021. https://www.researchgate.net/publication/327 754944_Identifying_Public_Facilities_Surroundi ng_MRT_Stations_Based_on_Pedestrian_Walkin g_Distance_using_GIS-

Based_Buffer_and_Spatial_Query_Method_Case _study_Central_and_South_Jakarta.

5. Transportation Research Board. Highway Capacity Manual.; 2000.

6. Miranda, E. A. S., Carrasco, J. G. Y., Pedestrian Volume Studies: A Case Study in the City of
Gothenburg, Sweden. Published online December 2011.

7. Shaaban, K., Muley, D., Investigation of Weather Impacts on Pedestrian Volumes. In: Transportation Research Procedia. Vol 14. Elsevier B.V.; 2016:115-122. doi:10.1016/j.trpro.2016.05.047.

8. Sulaksono Wibowo S., Nurhalima, D. R. M., Pedestrian Facilities Evaluation using Pedestrian Level of Service (PLOS) for University Area: Case of Bandung Institute of Technology. Munawar A, SuryoPutranto L, Zhang J, et al., eds. MATEC Web of Conferences. 2018;181:02005. doi:10.1051/matecconf/201818102005.

9. Dias, I., Development of an Evaluation Criterion to Assess Pedestrian Facilities in Urban Environment using Walkability Measures. Published online 2012. https://www.researchgate.net/publication/325 894953_Development_of_an_evaluation_criterio n_to_assess_pedestrian_facilities_in_urban_envi ronment_using_walkability_measures?channel= doi\&linkId=5b2b444aaca27209f3797db0\&showF ulltext=true.

10. Walk Score. How Walk Score Works. Published 2020. Accessed January 31, 2021. https://www.walkscore.com/how-it-works/

11. Nuworsoo, C., Cooper, E., Cushing, K., Jud, E., Integration of Bicycling and Walking Facilities into the Urban Communities Infrastructure Of.; 2012. Accessed January 31, 2021. http://transweb.sjsu.edu

12. Mohammed, A. A., By Using Model Shift and Improving The Walking Facilities: A Case Study In Kuala Lumpur, Malaysia. International Journal of Advances in Applied Sciences. 2014;3(4):195. doi:10.11591/ijaas.v3.i4.pp184-195.

13. Nai, W., Dong, D., Chen, S., Zheng, W., Yang, W., Optimizing the Usage of Walking Facilities between Platform and Concourse Layer in LShaped Interchange Metro Station. Procedia Social and Behavioral Sciences. 2012;43:748-757. doi:10.1016/j.sbspro.2012.04.148.

14. Linkon, F. D., Ashek, A. A. N., Singha, P. K., Walkability Indices for a Major Urban Arterial of Dhaka City | Request PDF. In: 4th International Conference on Advances in Civil Engineering 2018 (ICACE 2018). ; 2018. Accessed February 1, 2021. https://www.researchgate.net/publication/328 335199_Walkability_Indices_for_a_Major_Urban _Arterial_of_Dhaka_City.

15. Azmi, D. I., Karim, H. A., Ahmad, P., Comparative Study of Neighbourhood Walkability to Community Facilities between Two Precincts in Putrajaya. Procedia - Social and 
Behavioral Sciences. 2013;105:513-524.

doi:10.1016/j.sbspro.2013.11.055.

16. Cubukcu, E., Hepguzel, B., Onder, Z., and Tumer, B., "Active Living for Sustainable Future: A Model to Measure 'Walk Scores' via Geographic Information Systems," Procedia Social and Behavioral Sciences, vol. 168, pp. 229237, Jan. 2015, doi: 10.1016/j.sbspro.2014.10.228. 